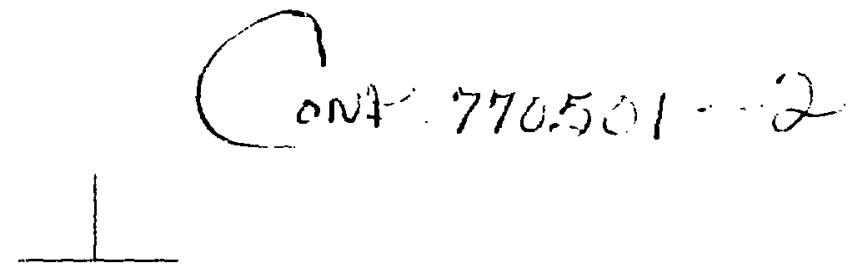

\title{
Estimation of Age Structure of Fish Populations from Length-Frequency Data*
}

\author{
K. Deva Kumar and S. Marshall Adams \\ Environmental Sciences Division \\ Oak Ridge National Laboratory \\ Oak Ridge. Tennessee
}

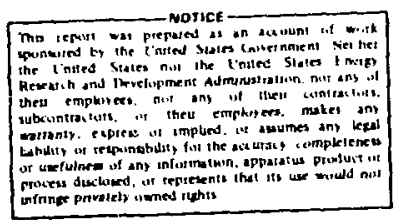

\section{ABSTRACT}

\begin{abstract}
A probability model is presented to deternine the age structure of a hish population from length-frequency data. It is stwo'n that when the atge-length key is available, maximum-likclihood estimates of the age structure can bi obtained. When the key is not available, approxinate estimares of the dge structure can be obtained. The model is used for determination of the age structure of populations of enannel catfish and white crappie. Practical applicutions of the model to mpact assessment are drscussed.
\end{abstract}

Kc. words: age-dength key, age structure, clannel catfish. leng1h-frequency distribution, maxumuin likelihond estinates, mixture of normals, probability model, simulation study, white crappie

\section{INTRODUCTION}

Fish monitoring programs ai nuclear power piants are designed to detect impacts and to ensure that these plants operate without causing unacceptable environmental damage. However, these monitoring programs, in genera', are תot comprehensive enough to detect impacts on fish populations due to power plant operations. Problems in the design of meaningful monitoring programs occur primarily because of the difficulties in sampling and interpreting monitoring data collecied in open aquatic systems under highly varicble envirunmental conditions. The inherent problems in sampling fish populations, such as size selectivity of sampling gear, mobility of fishes, and some of the behavioral characteristics of fish such as schooling, all tend to increase the effort and cost of an effective monitoring program.

Several approaches have been tried to c valuate the extent of changes in fish populations due to perlurbations. One approach attempts to detect changes in density but is very difficult to implement due to inherent problems in quantitative sampling. Tag and release methods seem bast for

* Research sponsored in part by the Energy Research and Development Administration under contract with Union Carbide Corporation and in part by the Nuclear Regulatory Commission Office of Nucleas Reactor Regulation under Interagency Agreement ERDA 40-554-75. ESD Publication No. 1040, Environmental Sciences Division, Oak Ridge National Laboratory. 


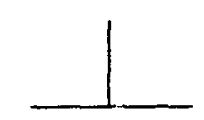

Age Structure from L_ength-Frequency Data

estimating the size of a fish population, but these programs are expensive and time consuming. Methods currently employed to monitor potential impacts of power plant operations on the density of fish populations include comparing the catch per unit effort between control and disct.arge areas and between preoperational and operational periods. However, interpretation of catch-per-uniteffort data and extrapolation to effects on a population are difficult. For example, higher catches of fish in a thermal area compared to catches in a control area or variations in cat thes from year to year may mean either that some redistribution of the population has occurred, or that a change in population structure has occurred, or both. For meaningful interpretation, this method requires obtaining estimates of the fish density of the entire aquatic system, which is difficult.

Another approach to monitoring fish pepulation dynamics involves the species structure. The best example of this is the comparison of fish diversity indices and similarity coefficients between discharge and control areas or between preoperational and operational periods. It is difficult, however, to relate changes in these indices to changes in the functional aspects of populations such as population growth, production, mortality, and age structure. Functional parameters, particularly production. can be used to quantify the ecological success of a species and to provide a measure of stress in aquatic ecosystems ((hadwick 1976). Functional parameters for evaluation of potential perturbations are also destrable because they reflect the dynamics of the entire system rather than of a single component. A clange in density may be reflected in changes in mortality and growth rates, unless mortality and growth ate density independent. If operation of a power plant is having a major impact on a fish population, then significant changes could possibly be expected in the mortality rate, growth rate, and production rate which in turn will be reflected in the age structure of the population.

In this paper we are interested in estimating the age structure of a fish population. Knowledge of the age structure is useful for the estimation of natural mortality, fishing mortality, and production (Ricker 1975, Seber 1973). Tie age-length key* is usually based on a subsample of the catch (Allen 1966), and the age distribution in the subsample is assumed to be an estimate of the age structure in the catch and, therefore, of the age structure in the population. The length-frequency distribution of a fish population is usually derived from either the total catch or a very large subsample. How. ever. due to the cost and effort involved, the age-length key is based on a much snaller sample. If the subsample chosen for aging is "optimal" (based on some criteria), then the age-length key method will yield reliable estimates of the age structure.

In the following sections we discuss a probability model for the length of a fish which takes into consideration the age-structure of the population and

*A double frequency table, usually with age in the coiumns and lengths in the rows (Ricker 1975, p. 206). 


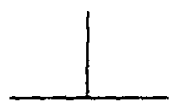

is estimated from length-frequency data. If an estimate of the ape-length key is available, reliable estimates of the age structure can be obtained, and even when this key is not available, the model gives a first approximation tor the age distribution. While the Allen estimator (see above) for the aye structure is a straight extrapolation from a subsample, this model attempts to use the larger sample associated with the length-frequency data to estimate the age distribution.

\section{MODELS FOR FISH LENGTH}

In this section we discuss a probability model for the length of fish. For a historical review of the model, see Ricker (1975).

Assume that there are $k$ age classes in a fish population, and that $p_{i}$ is the proportion of the population of age $i$. Let the lengths $x$ of fish of age $i$ be discributed normally with mean $\mu_{i}$ and variance $o_{i}{ }^{2}$. The probability density function $f(x: \theta)$ of $x$ for the population can be written as

$$
f(x: \Theta)=\sum_{i=1}^{k} \rho_{i} N\left(x: \theta_{i}\right) .
$$

where

$$
\begin{aligned}
\Theta & =\left\langle\theta_{1}, \theta_{2}, \ldots, \theta_{k}, \rho_{1}, \rho_{2}, \ldots, \rho_{k}\right\rangle . \\
\theta_{i} & =\left\langle\mu_{i}, a_{i}{ }^{2}\right\rangle .
\end{aligned}
$$

$N\left(x ; \theta_{i}\right)=$ density function of a normal distribution with mean $\mu_{i}$ and variance $\sigma_{i}{ }^{2}$,

$\rho_{i}=$ proportion of the population of age $i$,

$k=n$ umber of age classes in the population which is generally assumed to be known.

The parameter vector $\Theta$ is related to some well-known fishery statistics. For example, the catch curve* can be represented by the plot of $\log _{g} p_{i}$ against age $i$, and the plot of $\mu_{i}$ against age $i$ is the growth curve. If the variances of the individual normal distributions are small, then the lengtitfrequency plot will have $k$ well-defined modes at $\mu_{1}, \mu_{2}, \ldots, \mu_{k}$. If there are differential growth rates for various year classes, the modes may not be well defined. MacDonald (1971) attempted to estimate modes from the lengthfrequency data for fast-growing pike (Esocidac), and he was able to identify

*A graph of the logarithm of the number of fish taken at successive ages or sizes (Ricker 1975, p. 2). 


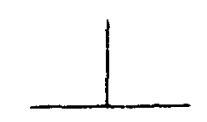

K. Deva Kumar and S. Marshall Adams

Eive separate age classes. For these data. the average distance between the mean lengths for successive age classes was $100 \mathrm{~mm}$. Separations this distinct would not be expecred for most smaller or slower-growing rish. In many cases small separations occur between age classes. especially between the middle ind uppes age class.

Age-length data for white crappe (Pomoxis annularis) presented in Table I show that distuct and latge differences between age classes after age class 2 do not occur. For example. the mean lengths $f_{u r}$ age classes 2 and 3 differ by anly $21 \mathrm{~mm}$ and the mean lengths for age classes 3 and 4 differ by only 28 anm. If the growth warve is modeled by the von Bertalanffy equation (Ricker 1975. P. 221, the average distance between the mean lengths of suciessive age dasses decreases as age increases. As a result. the estimation of all the param. eters in the vector $\Theta$ betomes vers difficult.

\begin{tabular}{|c|c|c|c|c|c|}
\hline \multirow{2}{*}{$\begin{array}{l}\text { Veat of } \\
\text { “̈lptuse }\end{array}$} & \multicolumn{5}{|c|}{ Average length 1 manl dt dpes 1 s } \\
\hline & $!$ & 2 & 3 & 4 & 5 \\
\hline 1960 & 117 & 188 & 220 & 247 & 278 \\
\hline 1967 & 101 & 171 & 2119 & 2.36 & 306 \\
\hline 194.8 & 114 & 18.3 & 2019 & 230 & 2411 \\
\hline 196,9 & $1: 7$ & $|9|$ & 214 & 2411 & 273 \\
\hline 1970 & 116 & 173 & 196 & 221 & 224 \\
\hline 1971 & 121 & 184 & 193 & 215 & $25:$ \\
\hline 1972 & 112 & 168 & 173 & 202 & 252 \\
\hline 1973 & 114 & 171 & 197 & 215 & 221 \\
\hline Mean & 115 & 179 & 20111 & 228 & 257 \\
\hline
\end{tabular}

Data from Mathur et al. (1975).

In Table 2 , the average $y$ arly increment in length for one-year -olds (two years old at the end of the given growing season) is presented for white crappie. Identification of the good and poor recruitment years is taken from Mathur et al. (1975). The average increase in length when recruitment was poor was about $75 \mathrm{~mm}$ and the average metease when recratment was good was only $48 \mathrm{~mm}$. This inverse relationship between growth rate and tecruis. ment success is probably due to inter-and intra-age-class cotnpetition for the same food source in the pond. Young white erappie (age classes $0-3$ ) in the pond consume mainly zooplankton (Euston 1976). When there is a large recruitment of young into the pond. individuals in age class 0 are competing for zooplinkton annong themselves and also with age classes $I$ and 2 . Consequently, during a good recruitment year, growth of these three age classes is slow, whereas during a pros recrutitment year, growth of these age classes is greater due to reduced competition for food. Also. during high recruitment

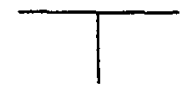




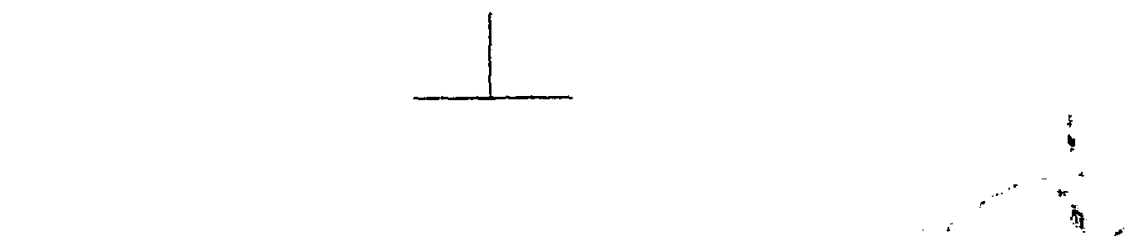

260 K. Deva Kuntar and S. Marshall Adams

Table 2. The effect of recruitment success on the grow th rate of age class I white crappie in Comowingo Pond ${ }^{a}$

\begin{tabular}{|c|c|c|c|c|}
\hline Year & $\begin{array}{l}\text { Recruitment } \\
\text { sucecss }\end{array}$ & $\begin{array}{l}\text { L.tength of uge } \\
\text { dians } 1 . \mathrm{mm}\end{array}$ & $\begin{array}{l}\text { Lengeth of afte } \\
\text { class ? mont }\end{array}$ & $\begin{array}{l}\text { Cirouth } \\
\text { mactment }{ }^{b} \mathrm{~mm}\end{array}$ \\
\hline 1966 & Ciroud & 117 & 188 & \\
\hline 1967 & Poot & 101 & 171 & 54 \\
\hline 1968 & Poor & 114 & $15:$ & $B=$ \\
\hline 1969 & Grood & $1=7$ & {$[4]$} & 79 \\
\hline 1970 & Poor & lie. & 173 & 46 \\
\hline 1971 & Gived & 121 & 184 & 68 \\
\hline 1972 & Pons & 112 & 165 & 47 \\
\hline 1973 & Poor & 114 & 171 & 54 \\
\hline 1974 & Averaye & 129 & 2112 & $8 S$ \\
\hline 1975 & Prist & no & 175 & It \\
\hline
\end{tabular}

\footnotetext{
dotis trom Mathut et at (1475)

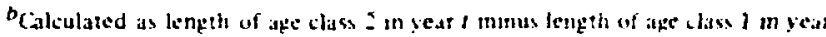
$t$ minus length of age clasi I tn year $8 \quad 1$
}

years for white crapple, the predaturprey tath in this system probahly decreases. Therefore, predation on young-of the -yedr white stappie would be reduced and probably would not be untensive enough to ulumately reduce the competition for food. Some large predators such as walleye largemouth bass. and smalimouth bass, are present in the system, but seemingiy $m$ small numbers (Mathur et al. 1975).

The previous discussion has indicated that there is alor always a direct correspondence between the modes in length-frechueney dalj and the ages present in the catch. Because the age length key is based on a subsample. it would be, in general. more efficient to use the larger sample associated with the length-frequency data to estimate the age-structure. This can ba accon?. plished by obtaining the mean lengths of the various age classes $(\mu$, "s). Once the $\mu_{1}$ s are known. the reduced parameter vector $\Omega=\left\langle\sigma_{1}{ }^{2} . \sigma_{:}{ }^{2} \ldots \ldots \sigma_{k}{ }^{2} . \rho_{1}\right.$. $\left.\mu_{2}, \ldots . \mu_{h}.\right\rangle$ can be crtimated: that is inslead of estimatmy $h$ means. $k$ variances. and $k-1$ proportions, we estumate $k$ varlances and $k-1$ propor. tions.

Additionally. if the variances $\sigma_{i}{ }^{2}$ can be estimated from the subsample employed for obtaining the age-length key, then the only urknowns are the $k$ - I proportions. The estimate of $\Omega$ will be referred to as the conditional maximum likelihood (CML) estimate. and the estimate of $\Theta$ defined in Eq. (1) will be refetred to as the maximum likelihood (ML) estimate. This method will be applied to some fish catch data. 


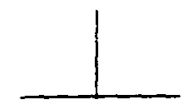

Age Siructure from Length-Frequency Data

\section{ESTIMATION OF THE PARAMETERS OF THE MODEL}

The estimation of the parameters of a mixture of two normal distributoms (also referred to as a compound normal distribution) has been investipated by Cohen (1967). Pearson (1894), and Rao (1952). Pearson (1894) derived the moment estimator for $k=2$ and Cohen (1966) found that for sample sizes less than 400 the moment estumators were not very reliable.

Hasselblad (1966) has investigated the properties of the maximum likelihood estimators for a moxi ure of $k$ numal distrabuitons. He reported titat (1) as $d_{\prime \prime}=\psi_{1}, \quad \mu_{j}$ ldecreases. the varances of the proportions $\rho$ merease rapidly: $(2)$ as $d_{n}$, jecreases, the variances of the locatior (i.e.. $\mu$ ) and scale (i.e.. $o$ ) estimators increase: and (3) as $\rho_{2}$ approaches 0 . the variances of the location and scale estimates increase. Hasselblad suggested an iterative method for the unaximum likelihood estimator. Dhck and Bowden (1973) used the Newton terative scheme for a mixture of Iwo normal distributions.

Maclkmald (1971) obtained estimates that ininimize the Cramer-von

Mises stutistic* (Cramer 1974. p. 451), and Kumar and Nicklin (1976) ubtamed estimates that minumized the mean squared distance between the enupincal and theoretical characteristic function. In this paper, we restrict arrselves so the maximum likelihood estimator. It is beyond the scope of this fraper to compare the various estimators.

The likelihood function is uonlmear in the parameters. $\theta$. It was felt that when $k$ is grteater than 2 . methods based on demvatives become ineiticient and the amount of computer tume required tends to render tha method imprattical. Destribed belou is an alternative method for astmattot of the parameters (E. 11. Nicklin. General Foods Corporation. White Plituns. Neu York. porsinat commencation). The negative of the natural logarntinn of the likelihood iunction $L$ given by

$$
L=-\sum_{j=1}^{n} \ln f\left(x_{i} ; \theta\right)
$$

was minumized with respect to $\Theta$ (or $\Omega$ ) using the derivative-free minimizatiun techmianue developed by Nelder and Mead (1965). This method is called the simplicial triangulation method. The method involves the evaluation of the function at the vertices of an $m+1$ dimensional moving simplex ( $m$ is the number of parameters to be estimated). Based on the functional values at tire verices, the simplex moves away from the maximum calculated value. This technique has been found to be efficient for most well-behaved surfaces.

In oides to keep the search for optimal values in the feasible region, transformed parameters were estimated. The location parameters (i.e., $\mu_{i}$ )

*The Cramer-von Mises statistic is a goodness of fit criterion for testing distributional assumptions.

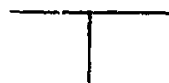




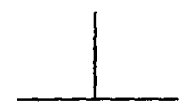

were restricted to the interval $\left[x_{(1)}, x_{(n)}\right]$, where $x_{(1)}$ and $x_{(n)}$ are the observed minimum and maximum values. The transformed means are given by

$$
\alpha_{i}=\ln \left[\mu_{i}-x_{(1)}\right]-\ln \left[x_{(n)}-\mu_{i}\right]
$$

This transformation is called the logistic transformation. The scale parameters have to be nonnegative, and this was achieved by using the transformation

$$
\lambda_{i}=\operatorname{in}\left(n_{i}^{2} / 2\right) .
$$

Finally, since the proportions $\rho_{i}$ must sum to unity, we need to estimate only $k-1$ proportions. However, these $]$ roportions must also satisfy the condition

$$
\sum_{i=1}^{k-1} p_{i} \leq 1-b
$$

where $b$ is some small positive constant less than 1 . The constant $b$ is intrnduced to prevent the pathological case of one of the proportions going to 0 or 1 . and it is usually chosen to be some function of the sample size $n$. Inequality (5) can be rewrinter as

$$
\begin{aligned}
& b \leq \rho_{1} \leq(1-b)=l_{1} . \\
& b \leq \rho_{i} \leq\left(1-b-\sum_{j=1}^{i} \rho_{i}\right)=l_{i} \quad 2 \leq i \leq k-1 .
\end{aligned}
$$

The transformed proportion is

$$
\delta_{i}=\ln \left(\rho_{i}-b\right)-\ln \left(l_{i}-\rho_{i}\right) \quad 1 \leq i \leq k-1 .
$$

Note that the ordering of $i$ is not important.

\section{EMPIRICAL EVALUATION OF THE ESTIMATION TECHNIQUE}

In the preceding section the problems involved in the estimation of the parameters were discussed. An empirical study of a hypothetical population was conducted to determine the advaritages of knowing, a priori, the mean length for each age class. The growth of a fish was assumed to follow the Bertalanfry growth curve. The average lengths for ages $1-5$ were assumed 10 be $117,156,190,220$, and $245 \mathrm{~mm}$, respectively, and the proportions of 


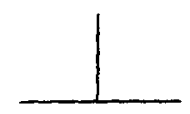

Age Structure from Lengtt-Frequency Data

each of the five age classes were set to $0.13,0.40 .0 .24,0.144$, and 0.086 , respectively. These proportions were assigned by :ssuming that the annual survival rate between ages 2 and 5 was 0.60 per year and that age 2 was the first fully recruited age class and constituted $40 \%$ of the total fish population.

The estimates of the proportions in each age class were obtained when (a) none of the parameters were known $(\theta)$, and $(b)$ when mean lengths were assumed known $(\Omega)$. The common variasce $\sigma^{2}=\sigma_{i}{ }^{2}: i=1.2, \ldots .5$ was varied bet ween 100 and 400 .

A sample of 1000 fish was generated from the population described above. Five sets of expected order statistics from a nurmal distribution (Harter, 1952) witn sample sizes $130,400,240,144$, and 86 were obtained, and the pararneter vectors $\Theta$ and $\Omega$ were estimated with the approprate variance. These estimates represent the "expected" behavior of the estimates. in the sesse that if the methodology does not work for this sample. it is highly doubtfui that it will work with a random sample. The results are summarized in Table 3 and Fig. 1 for the paraneter vector $\Theta[$ case (a)] and in Table 4 and Fig. 2 for the parameter vector $\Omega$ [case $(b)$ ].

For case $(a)$, the estimated values oi the elements of the parameter vector $\Theta$ show considerable variation from the "true" values. When the vanance is 400. the proportion $\rho_{2}$ is estimated to be $14 \%$. Whicrass in iact, the true value is $40 \%$, and $\rho_{3}$ is estimated to be $40 \%$, whereas the true value is $24 \%$ (Table 3). The estinated means and variances also show considerable departure from the true values. The estimated catch curves (Fig. 1 ) are also significantly different from the "true" catch curve. When the variance is 300 , the estimated $\rho_{S}$ is 0.20 and $\rho_{4}$ is 0.15 , giving a falsc impression that there is differential recruitment and mortality for the two years: also. when the variance is 400 , the estimated model indicates that age classes 1 and 2 are partially recruited and age 3 is the first fully recruited age class. In the assumed population. only age 1 is partially recrujted (the initial ascending limb of the curves represent partially recruited age classes, Ricker 1975 , p. 33).

The results for case $(b)$ are sunmarized in Table 4 . Considerable improvement is observed in the estimates of the proportions. For example, when the variance is 400 , the estiniated proportions : re reasonativy close to the true values, as upposed to case (a). The estinated a tch curves are plotted in Fig. 2. For snaller variances the estimated catch curves almost overlap the true catch curve. As the variance increases, the estimated catch curves tend to depart from the true curve, though this departure is not significant. As the variance increases, the estimated variances also exhibit greater departure from the true values, as one would expect.

* An expected order statistic is defined as follows. If $x_{1}, x_{2}, \ldots, x_{n}$ is a sample of size $n$ such that $x_{1}<x_{2}<\ldots<x_{n}$, then $E\left|x_{j}\right|=$ expected ordes statistic, where $E[\cdot]$ is the usual expectation operator. 


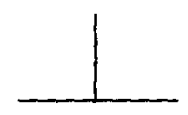

K. Deva Kumar and S. Marshall Adams

Table 3. Case (o): Estimates of the parameter vector $\theta$ from a sample of expected order statistics $(n=1000)^{p}$

\begin{tabular}{|c|c|c|c|c|c|c|}
\hline \multirow{2}{*}{$\begin{array}{c}\text { True } \\
\text { variance } \\
\left(a^{2}\right)\end{array}$} & \multirow{2}{*}{ Estimator ${ }^{b}$} & \multicolumn{5}{|c|}{ Afe class } \\
\hline & & 1 & 2 & 3 & 4 & 5 \\
\hline 100 & $\begin{array}{l}\hat{\mu} \\
\hat{o}^{2} \\
\hat{p}\end{array}$ & $\begin{array}{l}117.1 \\
98.1 \\
0.126\end{array}$ & $\begin{array}{l}156.2 \\
103.9 \\
0.4117\end{array}$ & $\begin{array}{c}188.11 \\
718.8 \\
0.178\end{array}$ & $\begin{array}{l}2117.5 \\
145.9 \\
4114\end{array}$ & $\begin{array}{l}233.7 \\
225.8 \\
11175\end{array}$ \\
\hline 200 & $\begin{array}{l}\hat{\mu} \\
\hat{a}^{2} \\
\hat{D}\end{array}$ & $\begin{array}{c}115.5 \\
174.2 \\
0.1 \mathrm{i}\end{array}$ & $\begin{array}{r}152.0 \\
170.4 \\
0.31\end{array}$ & $\begin{array}{r}1754 \\
214.2 \\
0.22\end{array}$ & $\begin{aligned} 2111.5 \\
218.8 \\
11.18\end{aligned}$ & $\begin{array}{l}3.4 .5 \\
3112.4 \\
0118\end{array}$ \\
\hline 300 & $\begin{array}{l}\hat{\mu} \\
\hat{o}^{2} \\
\hat{\rho}\end{array}$ & $\begin{array}{l}116.1 \\
293.4 \\
0.125\end{array}$ & $\begin{array}{r}150.8 \\
2410.01 \\
0.290\end{array}$ & $\begin{array}{l}174.9 \\
229.0 \\
01.231\end{array}$ & $\begin{array}{l}211.7 \\
185.8 \\
11.146\end{array}$ & $\begin{array}{l}232.1 \\
4124 \\
01.2112\end{array}$ \\
\hline 400 & $\begin{array}{l}\hat{\hat{\omega}} \\
\hat{\sigma}^{2} \\
\hat{\rho}\end{array}$ & $\begin{array}{l}114.8 \\
337.2 \\
0.126\end{array}$ & $\begin{array}{l}142.2 \\
191.9 \\
0.144\end{array}$ & $\begin{array}{l}169.6 \\
368.8 \\
0.399\end{array}$ & $\begin{array}{r}317.8 \\
323.6 \\
0.20 ?\end{array}$ & $\begin{array}{l}242.4 \\
365.11 \\
11.124\end{array}$ \\
\hline
\end{tabular}

${ }^{a}$ The true paraneter vector $\theta=\left\langle 117,156,190.220,245, a_{;}^{2}, \sigma_{s}{ }^{2}, \ldots, o_{s}{ }^{2}, 0.13\right.$. $0.411 .0 .24,0.144 .0 .086\rangle$ and $a^{2}=o_{1}^{2}, i=1.2 \ldots .5$.

$b_{\hat{\mu}}=$ estmated mean length. $\hat{\sigma}^{2}=$ estumated vardance, and $\hat{f}=$ motumated propurtusn

Table 4. Case (b): Estimases of the parameter vector $\Omega$ frum a sample of expected order statistics $(n=1000)^{\beta}$

\begin{tabular}{|c|c|c|c|c|c|c|}
\hline \multirow{2}{*}{$\begin{array}{c}\text { True } \\
\text { variance } \\
\left(o^{2}\right)\end{array}$} & \multirow{2}{*}{ Estimator $b$} & \multicolumn{5}{|c|}{ Age dass } \\
\hline & & 1 & 2 & 3 & 4 & $\vdots$ \\
\hline 100 & $\begin{array}{l}\hat{\mu} \\
\hat{o}^{2} \\
\hat{\rho}\end{array}$ & $\begin{array}{l}117 \\
98.2 \\
0.128\end{array}$ & $\begin{array}{l}156 \\
102.7 \\
0.406\end{array}$ & $\begin{array}{l}191 \\
9 \approx .3 \\
0.232\end{array}$ & $\begin{array}{l}220 \\
115.4 \\
0.152\end{array}$ & $\begin{array}{l}24.5 \\
99.3 \\
0.018 ?\end{array}$ \\
\hline 200 & $\begin{array}{l}\hat{\mu} \\
\hat{a}^{2} \\
\hat{\rho}\end{array}$ & $\begin{array}{l}117 \\
196.1 \\
0.13\end{array}$ & $\begin{array}{l}156 \\
198.6 \\
0.405\end{array}$ & $\begin{array}{l}190 \\
17.3 .8 \\
0.235\end{array}$ & $\begin{array}{l}220 \\
173.9 \\
0.144\end{array}$ & $\begin{array}{l}245 \\
189.0 \\
0.087\end{array}$ \\
\hline $301 t$ & $\begin{array}{l}\hat{\mu} \\
\hat{o} \\
\hat{\rho}\end{array}$ & $\begin{array}{l}117 \\
301.9 \\
0.137\end{array}$ & $\begin{array}{l}151 . \\
273.4 \\
0.383\end{array}$ & $\begin{array}{l}190 \\
285.9 \\
0.260\end{array}$ & $\begin{array}{l}2201 \\
212.6 \\
\quad 0.123\end{array}$ & $\begin{array}{l}245 \\
266.6 \\
\quad 0.097\end{array}$ \\
\hline 400 & $\begin{array}{l}\hat{\mu} \\
\hat{\sigma}^{2} \\
\hat{p}\end{array}$ & $\begin{array}{l}117 \\
348.6 \\
0.134\end{array}$ & $\begin{array}{l}156 \\
207.0 \\
0.403\end{array}$ & $\begin{array}{l}190 \\
287.0 \\
0.236\end{array}$ & $\begin{array}{l}220 \\
241.8 \\
0.121\end{array}$ & $\begin{array}{l}24.5 \\
351.0 \\
0.107\end{array}$ \\
\hline
\end{tabular}

DThe true parameter vector $\theta=\left\langle 117,156,190,220,245, \sigma_{1}{ }^{2}, \sigma_{2}{ }^{2}, \ldots, \sigma_{5}{ }^{2}, 0.13\right.$, $0.4 \jmath, 0.24,0.144,0.086\rangle$ and $\sigma^{2}=\sigma_{i}{ }^{2}, i=1,2, \ldots, 5$.

$b_{\hat{\mu}}=$ estimated mean lengih; $\hat{\sigma}^{2}=$ estumated variance; and $\hat{p}=$ estimated proportion. 


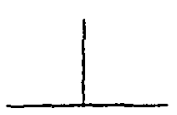

Age Structure from Length-Frequency Data

265

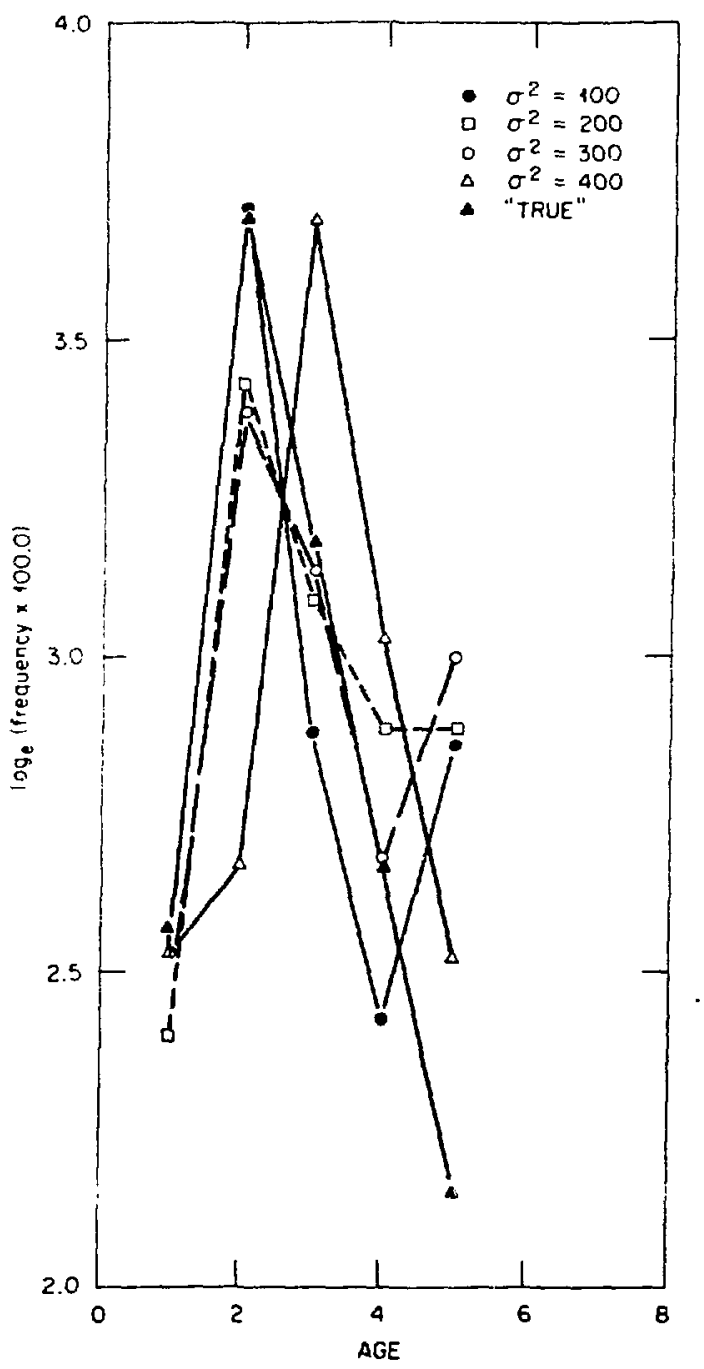

Fig. 1. Estimated catch curves when the full parameter vector $\theta$ is estimated for the expected order statistic and for $\sigma^{2}=100,200,300$, and 400 . 

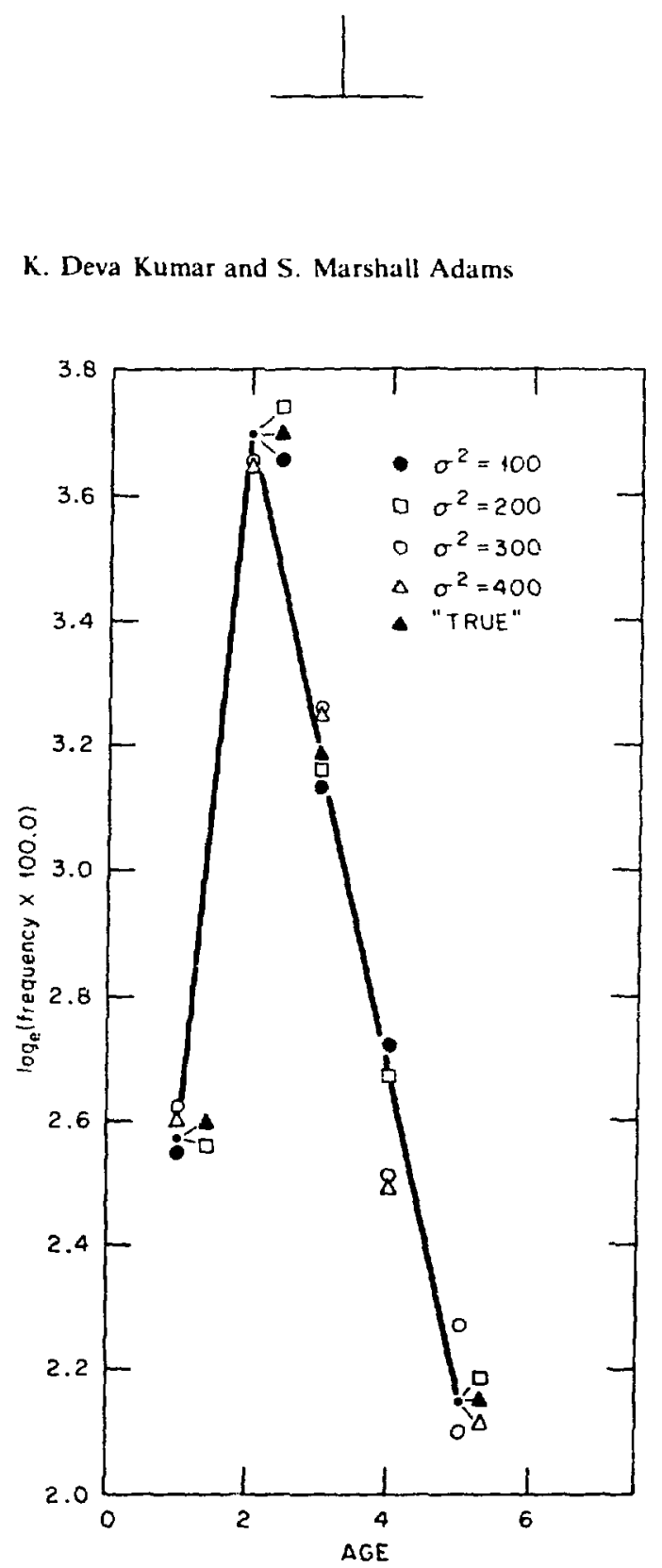

Fig. 2. Estimated catch curve when the location is assumed known and the reduced vector $\Omega$ is estimated for the expected order statistic and for $\sigma^{2}=100,200,300$, and 400.

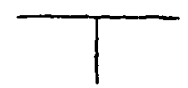




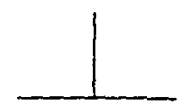

Age Siruciure from length-Frequency Data

267

These results show that if one has an age-length key aralable (case $(b)$ ). the jength-freyuency data can be used to ubtuin reliable estimates of the age structure of the pupulauon. When the key is not avalable. the estimates nust be viewed as first approximatoms. In the next section. the reaults of a small scale simulation study for case $(b)$ are presented.

\section{SIMULATION RESULTS}

The fish poptalatien was assumed to be the same as the above and 1he simulatums ince jun for two cases

$$
\begin{aligned}
& \text { (Cuse }) 0^{2}=0_{1}^{2}=100 \quad l=1.2 \ldots .5 . \\
& \text { (Cuse } 2) 0^{2}=0_{1}^{2}=200 \quad l=1.2 \ldots .5 .
\end{aligned}
$$

The bundin number: wete generated as follows. The sample size was ined at s000. The sample sires for the five nurmal distributions were 130 . 401. 240. 144. and 80 , respectively, hased on the proportions defined anove. lwenty toplate samples of logo tish essin wete obtained for each of the two

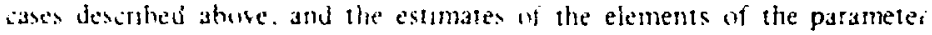

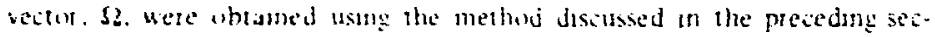

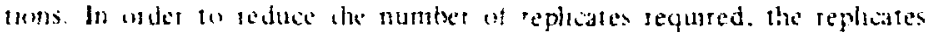
were regetiod if the Cramet-un Mases statusic based on the true values cxcerded 0.275. Hence, the repilicales used in the andysis represent a stran. fied sample from the population.

The results of the simulatrons for cases (1) and (2) are sumnarized in Tables 5 and 6 respectively. In both cases, the estimated proportinns are in

Tabje 5. Estimates of the parameter vector $\boldsymbol{\Omega}$ based on 20 replicates and a sample size of 1000 when the mean lengths are set equal to

\begin{tabular}{|c|c|c|c|}
\hline Patameses & True vislue & Mean estinate & Standist devistion \\
\hline$n:$ & 1011 & $0=+i$ & 16.50 \\
\hline$a_{2}=$ & 3611 & 1016.28 & 10.08 \\
\hline $0_{2}^{2}$ & 100 & $95.7 \mathrm{t}$ & 18.70 \\
\hline 0.2 & 1010 & 95.03 & 25.38 \\
\hline $0_{3}^{2}$ & 100 & 99.93 & 10.50 \\
\hline$\rho_{1}$ & 0.13 & 0.130 & $0.509(-2)^{e}$ \\
\hline$p_{2}$ & 0.40 & 0.399 & $0.111(-1)$ \\
\hline P, & 0.24 & 0.241 & $0.157(-1)$ \\
\hline$\rho_{4}$ & 0.344 & 0.145 & $0.143(-1)$ \\
\hline$p_{s}$ & 0.185 & 0.085 & $0.760(-2)$ \\
\hline
\end{tabular}
$117.156 .190,220$. and $245 \mathrm{~mm}$ and $a^{2}=a_{i}{ }^{2}=100 . i=1.2 \ldots .5$

$a_{0.509(-2)}=0.00509$. 


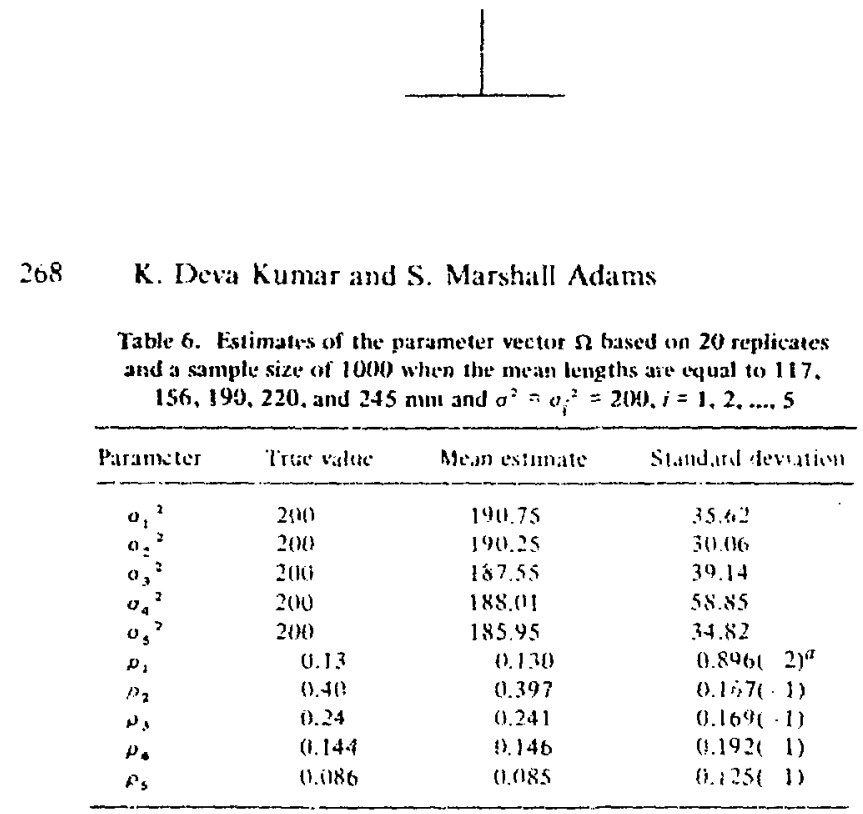

$a_{0.896(-2)}=0.01896$.

very good agreement with the "true" values. This result umplies that if the means of the populations are known a priori. then the proportions (catch curve) can be estimated with some reliability. The varianes, which are nuisance parameters. show gateater variability than the proportions and are gencrally biased dewnward. The standard deviations of the extimates of $a_{i}{ }^{2}$ increase with increasing $0^{2}$. as would be expected.

These results support the contusion we reached with the expected order statistics. 7hey demenstrate the feasihility of ohadining the CALL estimates from the length-fiequency data when flike age-length kcy is available.

\section{APPLICATIONS OF THE MODEL}

We now apply the techniques discussed above to two species of fish. channel catfish (ICtalurus pumesutus) and white crapjie (Pomoxis ammalaris). Length-frequency data for these two species were collected as part of the ecological monitoring program at the Peach Botton Atomic Power Station. The station. consisting of two units of $1065 \mathrm{MW}(\mathrm{c})$ each, is located in southeastem Pennsylvama on the west bank of Conowingo Pond, an innpounded reach of the Susquehanna River. Fish surveys with trap nets and trawls have been conducted at a series of stations lucated upstrean of the power plant (controls) and in areas expected to be within the hested plume. Monituring stations were lucated on the basis of available habitats and physical constraints imposed by topography. Length-frequency data and life-history information for the major species of fish in the pond are given in Robbins and Mathur $(1974,1976)$. In our study, length-frequency data of fish captured in trap neti were utilized. Trawl samples generally were dominated by age classes $0-2$, whereas fisl caught by trap nets were generally older and lager. 


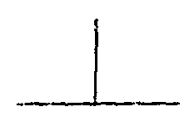

Figure 3 shows the length-frequency plot for the wap net catch of channel catrish in August 1971. Since the age-length key is not available for this species, we estimated all the parameters, $\Theta$, defined by Eq. (i). It was emphasized earlier that these estimates are only a first approximation. When none of the parameters are known, the estimation problem is more compljcated since in addition to the unknown parameter vector $\Theta$, and additional parameter $k$, the number of age classes in the probability model, is also unknown. Several values of $k$, therefore, will be used in at tempting: to fit the model, and the one that is most "satisfactory" will be used. The estimates of the elements of the parameter vecior $\Theta$ based on the data shown in Fig. $\$$ are sumnarized for $k=5$ and $k=6$ in Table 7 .

Table 7. Fstimates of parameter vector $\Theta$ for trap net data for channel catish collecled in August 1971 in Conowingo Pond

\begin{tabular}{|c|c|c|c|c|c|c|c|c|}
\hline \multirow{2}{*}{$j a$} & \multirow{2}{*}{$\begin{array}{c}\text { Sample } \\
\text { sine }\end{array}$} & \multirow{2}{*}{ Fstimatos $b$} & \multicolumn{6}{|c|}{ Modes } \\
\hline & & & 1 & 2 & 3 & 4 & 5 & 6 \\
\hline 5 & 345 & $\begin{array}{l}\hat{\mu} \\
\hat{o} \\
\hat{\rho}\end{array}$ & $\begin{array}{c}17 \\
9.4 \\
0.31\end{array}$ & $\begin{array}{c}153 \\
9.0 \\
0.18\end{array}$ & $\begin{array}{l}230 \\
25.1 \\
0.36\end{array}$ & $\begin{array}{c}261 \\
51.1 \\
0.11\end{array}$ & $\begin{array}{l}346 \\
37.4 \\
0.04\end{array}$ & \\
\hline 6 & 345 & $\hat{\hat{n}}$ & $\begin{array}{c}117 \\
9.4 \\
0.31\end{array}$ & $\begin{array}{l}153 \\
5.4 \\
0.16\end{array}$ & $\begin{array}{l}20.3 \\
33.3 \\
0.15\end{array}$ & $\begin{array}{c}236 \\
21.3 \\
0.22\end{array}$ & $\begin{array}{c}254 \\
35.0 \\
0.09\end{array}$ & $\begin{array}{l}320 \\
42.4 \\
0.07\end{array}$ \\
\hline
\end{tabular}

$a_{K}=$ number of uge classes ia the probability model.

$b_{\hat{\mu}}=$ estimated mean length, $\hat{a}=$ estimated standard deviatjon; and $\hat{\rho}=$ estimaled proportion.

For both $k=5$ and $k=6$, the first two modes are the same and the proportions are comparable. The mode at $230 \mathrm{~mm}$ for $k=5$ is separated into two modes at 203 and $236 \mathrm{~mm}$ for $k=6$. Clearly, the mode at $346 \mathrm{~mm}$ for $k=5$ represents all the remaining older age classes. The estimated proportion for this mode is only about $4 \%$ of the sample of 345 channcl catfish (i.e., ahout 14 fish). Ejther the species is short-lived or the trap nets are selective in that they do not capture the older age classes. The modes at 261 and $340 \mathrm{~mm}$ for $k=5$ are represented by modes at 254 and $320 \mathrm{~mm}$ for $k=6$. Also, some of the observations classified into modes 5 and 6 for $k=5$ are classified into mode 4 with a mean length of $236 \mathrm{~mm}$ for $k=6$. Even though we have associated a mode with a specific age class (e.g., mode 1 corresponds to age class 1), this is only a convenient way of referring to the modes.

Mathur et al. (1975) reported that the average lengths for channel catfish in Conowingo Pond between the years 1966-1969 for age classes 1-6 were $88, \mathrm{I} 49, \mathrm{I} 98,226,254$, and $288 \mathrm{~mm}$, respectively. For age classes $2-5$ the agreement between the estimated mean lengths and these seported values is

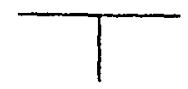



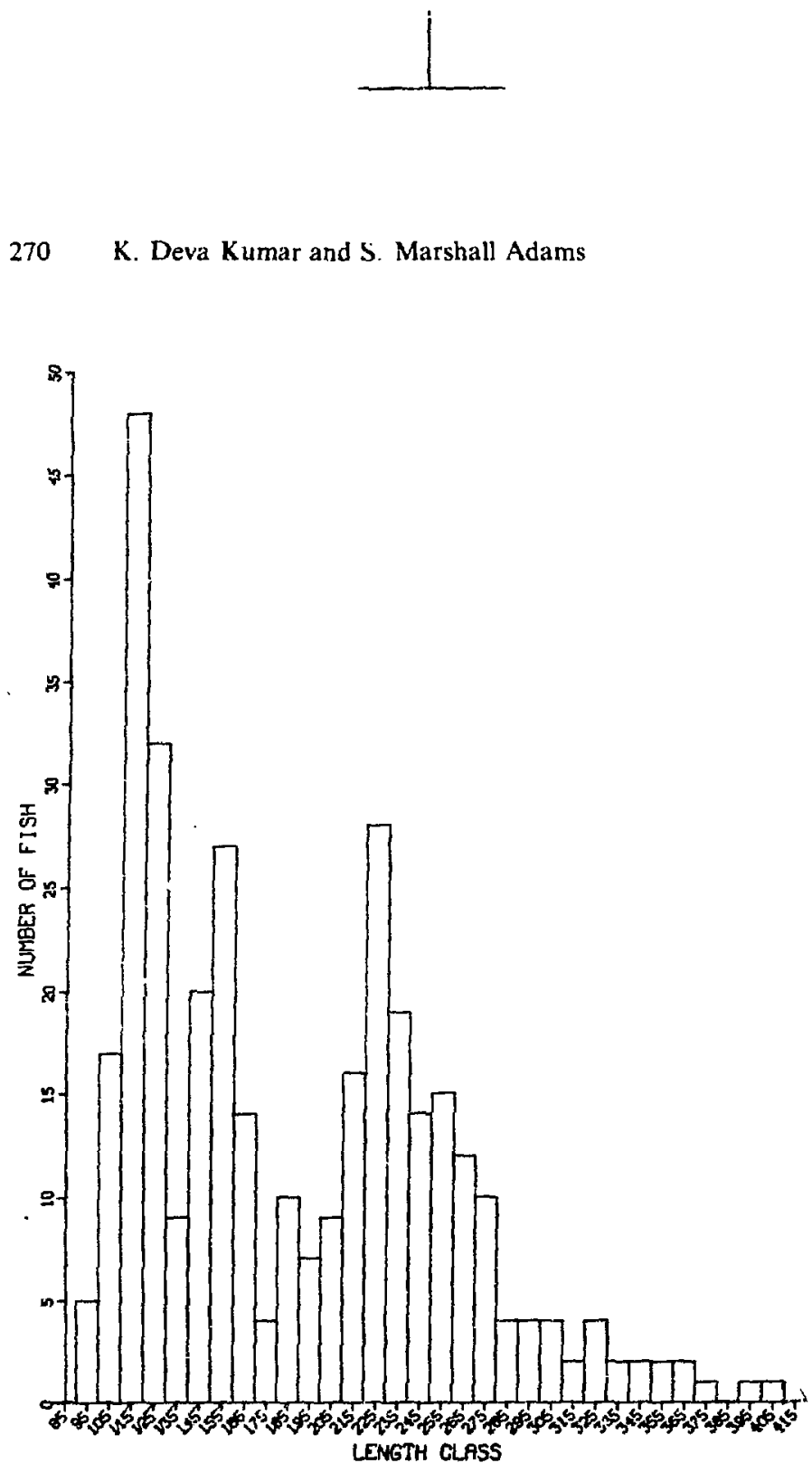

Fig. 3. Length-frequency data for channel catfish collected by trap nets in Conowingo Pond during August 1971. 


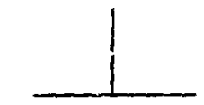

Age Structure from Length-Frequency Data

reasonable (Table 7). The large discrepancy for age class 1 may be due to the selectivity of trap nets for the larger individuals in age class $I$ or to a higher than normal growth rate for the 1970 year class.

The estimated standard deviations for age classes $3-6$ are relatively large (Table 7). Since few channel cat fish in the olcier age classes were caught, the estimated variances are only approximate. If the species is short-lived, the sample could be treated as representative of the true population. Otherwise, collection methods to obtain a more representative sample of the older age classus may be needed. The majority of specimens captured in Conowingo Pond are less than eigh years old, but a few fish in age classes 8-16 have been captured (Robbins and Mathur 1974). Davis (1959) and Finnell and lenkins (1954) found that channel catfish in Kansas and Oklahoma, respectively, seldom live longer than seven years. In contrast, $60 \%$ of the char 21 catfish collected by Stevens (1959) from two aquatic systems in South Carolina were eight years old or older. Age class structure and longevity of channel catfish may therefore be a function of the particular aquatic system concerned. Under the assumption that the catch was representative of the channel catfish population in Conowingo Pond in August 1971, the estimated catch curve is given by curve (a) in Fig. 4 for $k=6$. The effect of variable recruitment among year classes is pronounced, as indicated by the departure of the curve from a straight line.

Cases could be encountered where the nodes are too close to each other to represent separate age classes. Such would be the case when the spawning period of a species extends over a long period. Fish spawned in the early part of the period might have a higher mean length than those spawned towards the end of the period. The availability of food in different locations and interand intra-species competition for food may also play a strong role in creating multiple modes for the same age class. This situation probably exists in Conowingo Pond for white crappie and particularly for channel catfish. The growth of ulder channel catfish is relatively slow, and the growth of younger catfish is relatively rapid in Conowingo Pond. The average lengths of catfish in age classes 1 and 2 are greater than the lengths of the corresponding age classes in other aquatic systems. Conversely, the average lengths for age classes 3 and older are less than in other systems. Young catfish feed on zooplankton for about two years; thereafter, they assume a more benthic existence and consume greater quantities of benthos. Since the standing crop biomass of benthos is very sparse in the system, competition for this food source is high, and consequently, growth is slow. If two modes are close to each other due to differential growth within a single age slass, it may become necessary to subdivide the age classification further. Alternatively, one could take the mean of the two modal lengths.

Arother example for channel catfish is given in Fig. 5 and Table 8 for the June 1975 trap net data for $k=5$ and $k=6$. The modal lengths are the same for mode 1 and for mode 2 . The large standard deviation associated with the 


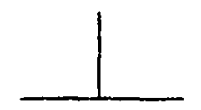

K. Deva Kumar and S. Marshall Adams

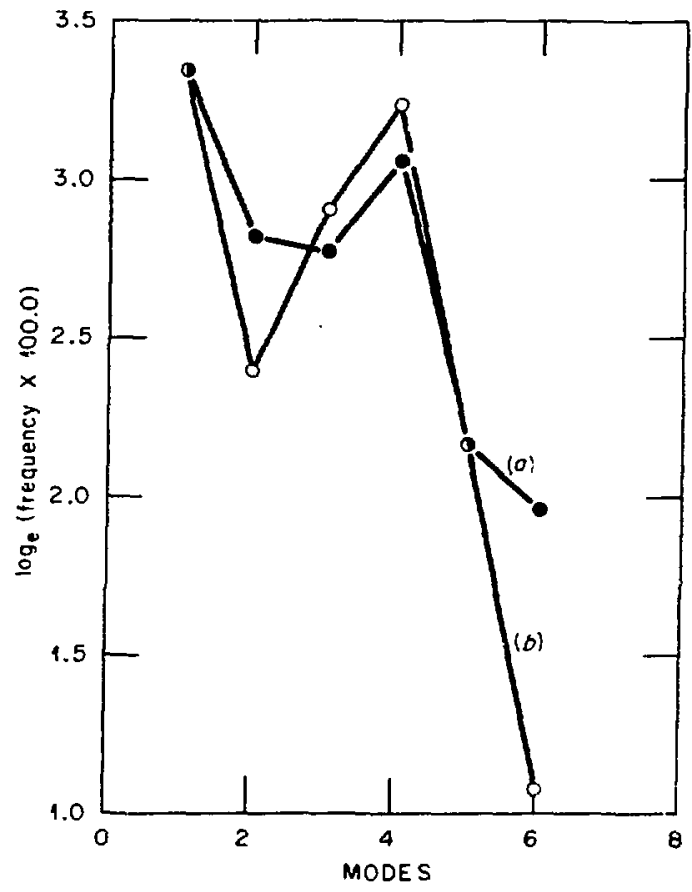

Fig. 4. Estimated catch curves for channel catfish: (o) August 1971 (Table 7). (b) June 1975 (Table 8).

Table 8. Estimates of parameter vector $\theta$ for Irap net data for channel catfish collected in June 1975 in Conowingo Pond

\begin{tabular}{|c|c|c|c|c|c|c|c|c|}
\hline \multirow{2}{*}{$k^{a}$} & \multirow{2}{*}{$\begin{array}{c}\text { Sample } \\
\text { size }\end{array}$} & \multirow{2}{*}{ Estimator $^{b}$} & \multicolumn{6}{|c|}{ Modes } \\
\hline & & & 1 & 2 & 3 & 4 & 5 & 6 \\
\hline 5 & 314 & $\begin{array}{l}\hat{\mu} \\
\hat{\sigma} \\
\hat{\rho}\end{array}$ & $\begin{array}{c}10.3 \\
16.3 \\
0.32\end{array}$ & $\begin{array}{l}152 \\
7.9 \\
0.14\end{array}$ & $\begin{array}{c}195 \\
26.0 \\
0.46\end{array}$ & $\begin{array}{l}275 \\
28.7 \\
0.16\end{array}$ & $\begin{array}{c}369 \\
30.0 \\
0.02\end{array}$ & \\
\hline 6 & 314 & $\begin{array}{l}\hat{\mu} \\
\hat{\sigma} \\
\hat{\rho}\end{array}$ & $\begin{array}{c}103 \\
16.2 \\
0.31\end{array}$ & $\begin{array}{l}153 \\
7.2 \\
0.12\end{array}$ & $\begin{array}{c}177 \\
22.5 \\
0.18\end{array}$ & $\begin{array}{l}201 \\
22.7 \\
0.27\end{array}$ & $\begin{array}{c}255 \\
30.9 \\
0.09\end{array}$ & $\begin{array}{c}349 \\
42.5 \\
0.03\end{array}$ \\
\hline
\end{tabular}

$a_{k}=$ number of age classes in probability model.

$b_{\hat{\mu}}^{\hat{\mu}}=$ estimated mean lengih; $\hat{\sigma}=$ estimated standard deviation; and $\hat{p}=$ estimated proportion. 


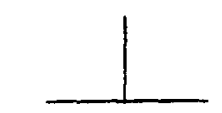

Age Structure from Length-Frequency Data

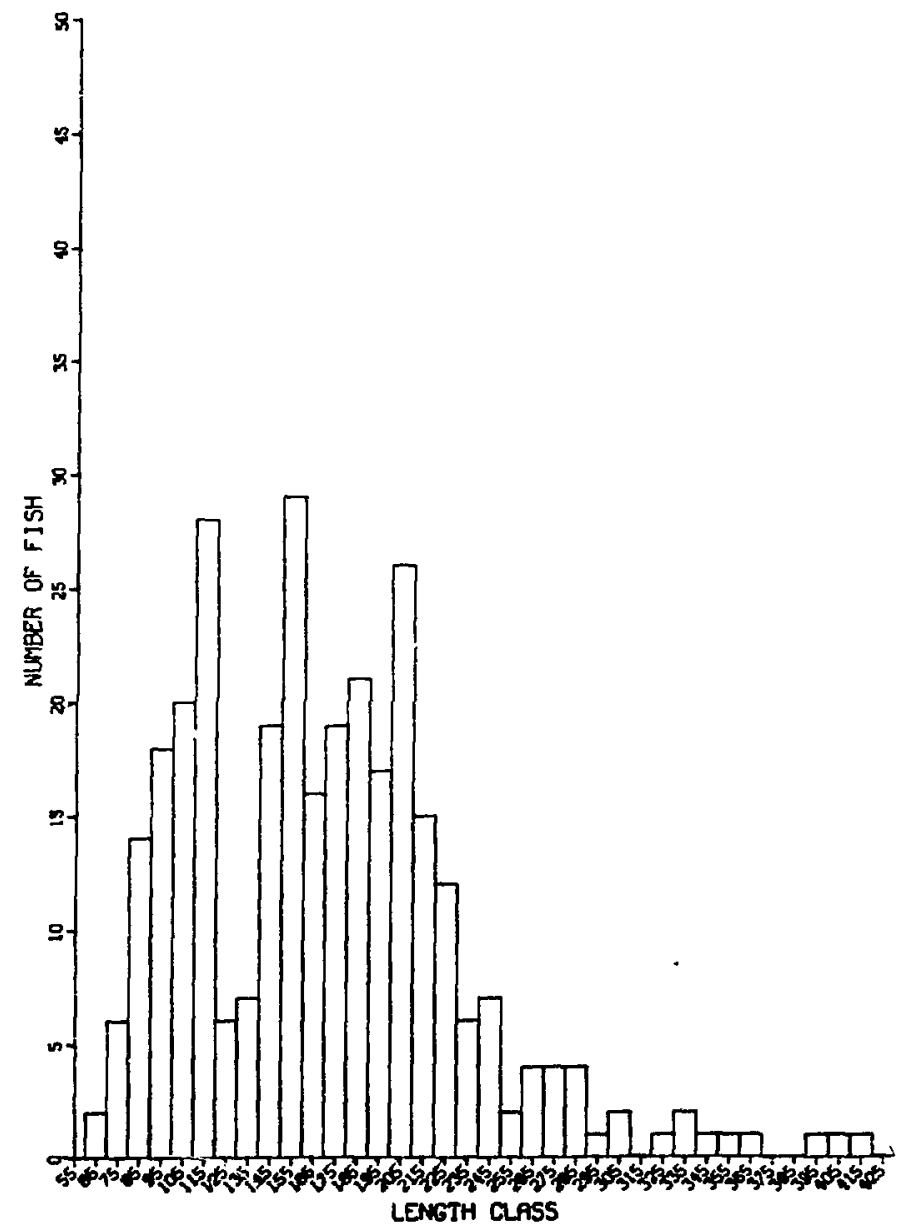

Fig. 5. Length-frequency dats for channel calfish collected by trap nets in Conuwingo Pond, June 1975.

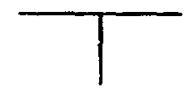




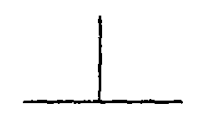

\section{K. Deva Kumar and S. Marshals Adams}

mode at $103 \mathrm{~mm}$ is due to the presence of age class 0 . as indicated by a minimum length of $65 \mathrm{~mm}$ for fish in the sample. When $k=5$ there appears to be a large separation between modes 3 and 4 and between modes 4 and 5 . Also, for mode $3, \rho_{3}=0.46$, a proportion too high to be true. When $k=6$, the modes are realigned, and there is a mode at $177 \mathrm{~mm}$, which is $24 \mathrm{~mm}$ from the previous mode at $153 \mathrm{~mm}$. Based on the estimated standard deviation at mode 2 , a length difference of $24 \mathrm{~mm}$ represents approximately 30 . The standard deviation at mode 3 is much larger $(22.5 \mathrm{~mm})$ than the standard deviation at mode $2(7.2 \mathrm{~mm})$, which indicates that mode 2 is about 10 away from mode 3 . It is evident that due to Jifferential recruitment and growth patterns, the age classes $3-5$ have overlapping length distributions. The estimated catch curve for $k=6$ is given by curve $(b)$ in Fig. 4 . The peak at mode 4 indicates differential growth rate.

A third example is the trap net data for white crappie collected in Conowingo Pond during January, February, and March of 1974. The lengthfrequency data for each of the three months are shown in Figs. 6-8. The age-length key (Table 1) is based on samples caught during the nongrowing season (i.e., the winter months). Since January-March 1974 wotrid be part of the nongrowing season of 1973, the age-length key should apply to the January-March 1974 data. The reported difference in mean lengths between age classes 4 and 5 is only $6 \mathrm{~mm}$ for 1973 (Table 1). However, since this value is based on a small sample, it is not very reliable. The length-frequency curves for these three months (Figs. 6-8) show that there are few fish between 160 and $180 \mathrm{~mm}$ (less than $2 \%$ of the catch in January). Since 1972 was classified as a year of poor recruitment (see Table 2), the proportion of age class 2 in the population in 1974 would be expected to be small.

In Table 9 the estimates of the full parameter vector $\Theta$ for each of the three months are summarized. In January, modes 1 and 2 occur at 125 and $136 \mathrm{~mm}$, and these two modes together (year classes 1972 and 1973) constitute $59 \%$ of the catch, which is in direct conflict ivith the recruitment classification of Table 2. At the present time we are unable to resolve this conflict. The same pattern for modes 1 and 2 is also observed in February (68\%) and March (80\%). In February and March of 1974 mode 1 is at $116 \mathrm{~mm}$, which is reasonably close to the reported mean length for 1973 of $114 \mathrm{~mm}$ in Table 1 .

There exists, however, a second mode at approximately $135 \mathrm{~mm}$ for all three months. According to the age-length key (Table 1), this mode must represent age class 1 fish, since age class 2 had an average fength of $171 \mathrm{~mm}$ in 1973. This result indicates that the mode at $335.0 \mathrm{~mm}$ represents the upper range for age class 1 in 1973. The mode at $116 \mathrm{~mm}$ that is present in February and March does not appear in January (Table 9). There are two possible explanations for the apparent discrepancy; either the average length for age class I was $130 \mathrm{~mm}$ in January 1974 or the catchability of fish less than $100 \mathrm{~mm}$ in length was low. Since the smallest fish caught was about 75 $\mathrm{mm}$, the average length for age class $I$ is probably $130 \mathrm{~mm}$. 

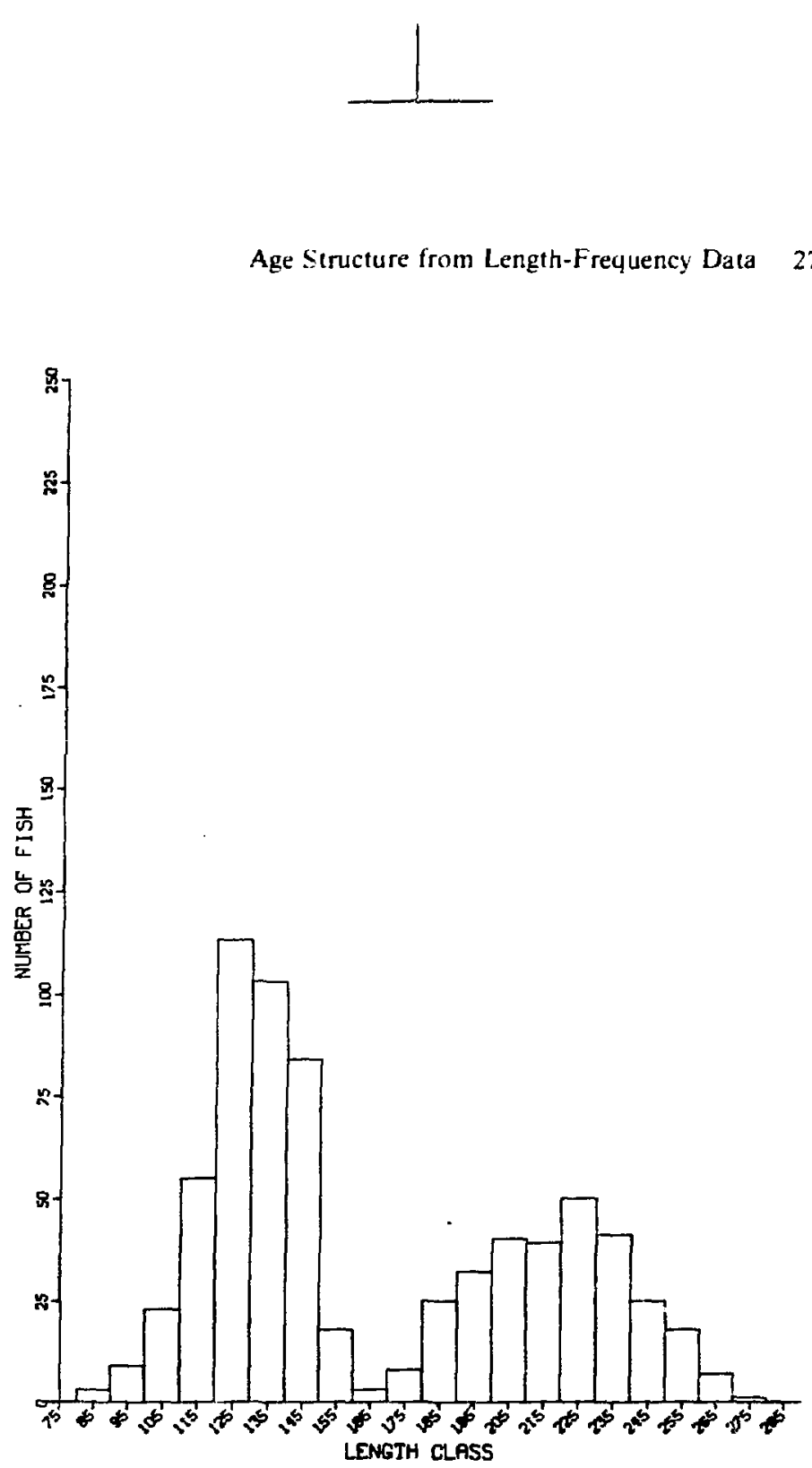

Fig. 6. Length-frequency data for white crappie collecied by trap nets in Conowingo Pond, January 1974. 


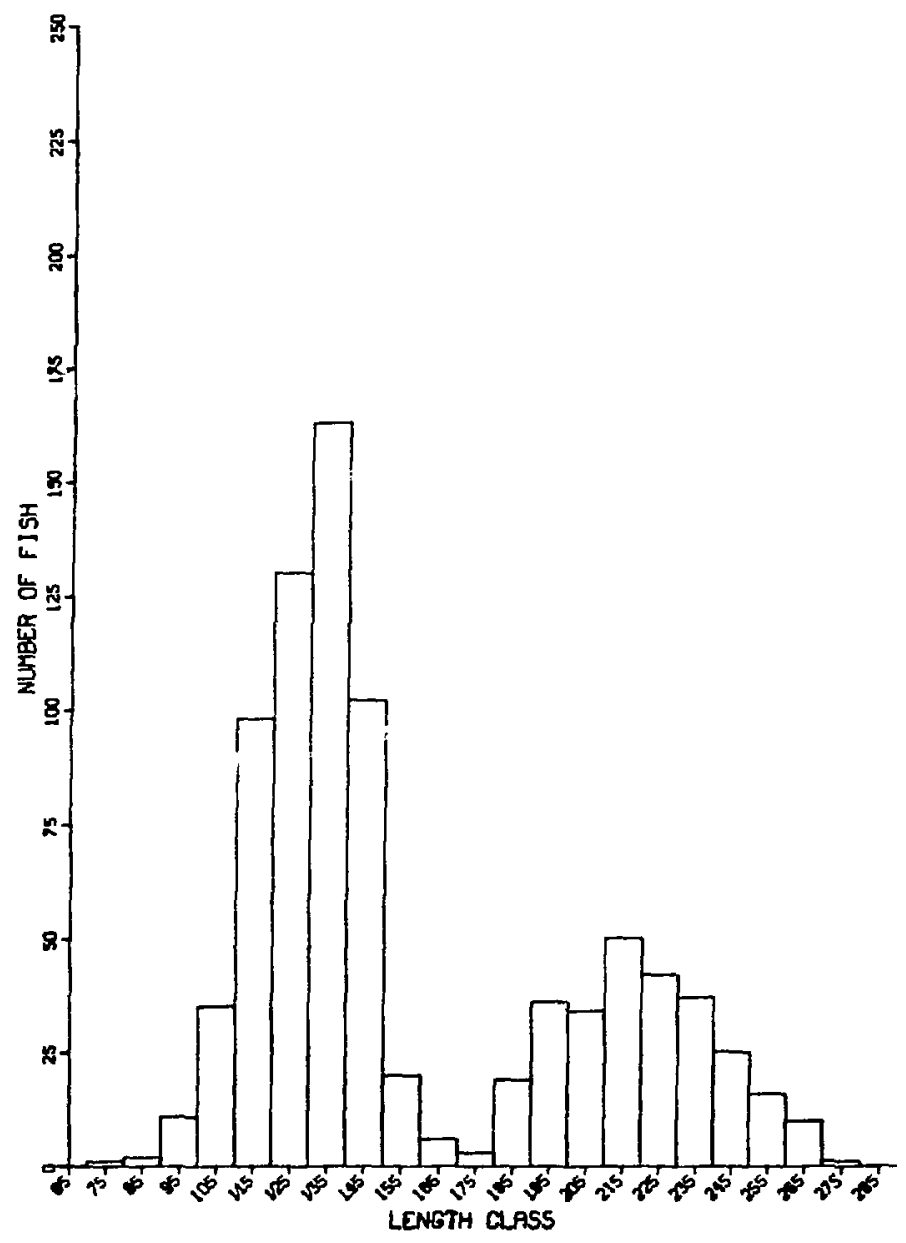

Fig. 7. Length-frequency data for white crappie coflected by trap nets in Conowingo Pond, February 1974. 


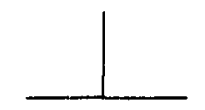

Table 9. Estimates of parameter vector $\theta$ for trap net data for white crappie collected in January, February, and March 1974 in Conowingo Pond

\begin{tabular}{|c|c|c|c|c|c|c|c|}
\hline \multirow{2}{*}{ Month } & \multirow{2}{*}{$\begin{array}{l}\text { Sample } \\
\text { size }\end{array}$} & \multirow{2}{*}{ Estimator } & \multicolumn{5}{|c|}{ Modes } \\
\hline & & & 1 & 2 & 3 & 4 & 5 \\
\hline January & 697 & $\begin{array}{l}\hat{\mu} \\
\hat{\sigma} \\
\hat{\rho}\end{array}$ & $\begin{array}{c}125 \\
15.1 \\
0.33\end{array}$ & $\begin{array}{c}136 \\
10.2 \\
0.26\end{array}$ & $\begin{array}{c}198 \\
13.5 \\
0.15\end{array}$ & $\begin{array}{c}223 \\
16.1 \\
0.13\end{array}$ & $\begin{array}{c}237 \\
15.4 \\
0.13\end{array}$ \\
\hline February & 841 & $\begin{array}{l}\hat{\mu} \\
\hat{a} \\
\hat{\rho}\end{array}$ & $\begin{array}{l}116 \\
12.9 \\
0.16\end{array}$ & $\begin{array}{l}133 \\
11.7 \\
0.52\end{array}$ & $\begin{array}{c}199 \\
13.2 \\
0.09\end{array}$ & $\begin{array}{c}214 \\
15.2 \\
0.10\end{array}$ & $\begin{array}{c}238 \\
15.8 \\
0.13\end{array}$ \\
\hline March & 1129 & $\begin{array}{l}\hat{\mu} \\
\hat{a} \\
\hat{p}\end{array}$ & $\begin{array}{c}116 \\
10.5 \\
0.28\end{array}$ & $\begin{array}{l}135 \\
10.5 \\
0.52\end{array}$ & $\begin{array}{l}194 \\
16.4 \\
0.04\end{array}$ & $\begin{array}{l}208 \\
13.8 \\
0.07\end{array}$ & $\begin{array}{c}232 \\
16.9 \\
0.09\end{array}$ \\
\hline
\end{tabular}

$a_{\hat{\mu}}=$ estimated mean length $: \hat{o}=$ estimated standard deviation; $\hat{\rho}=$ estimated propor tion.

The estimated modes for the three months are 198, 199, and $195 \mathrm{~mm}$ for age class 3 , which is in good agreement with the value of $197 \mathrm{~mm}$ from Table I. For age class 4 , the estimated modes for the three months are 223,214 , and $208 \mathrm{~mm}$. The wejghted average length in $\mathrm{mm}$ for age class $i$, $\bar{x}_{i}$, is computed by

$$
\bar{x}_{i}=\sum_{j} \frac{\left(\rho_{i j} C_{j}\right) \mu_{i j}}{\sum_{j} \rho_{i j} C_{j}}
$$

where

$$
\begin{aligned}
& \rho_{i j}=\text { proportion of age class } i \text { in the catch at time } j \\
& c_{j}=\text { total number of fish in the catch at time } j \\
& \mu_{i j}=\text { the } i \text { th estimated modal length (in mm) at time } j .
\end{aligned}
$$

The number of white crappie of all age classes caught in January, February, and March was 697,841 , and 1129 , respectively. The estimated weighted mean lengths for ages $3, \overline{4}$, and 5 are 198, 215, and $236 \mathrm{~mm}$, respectively. The estimates for ages 3 and 4 are in close agreement with the reported values of 197 and $215 \mathrm{~mm}$. The reported value for age 5 is $221 \mathrm{~mm}$ which is about $15 \mathrm{~mm}$ less than the estimated value.

In this example for white crappie, even though there was an estimate of the age-length key, the more general approach of estimating the elements of

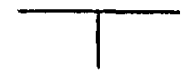




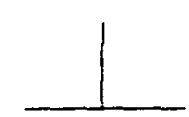

Age Structure from Length-Frequency Data

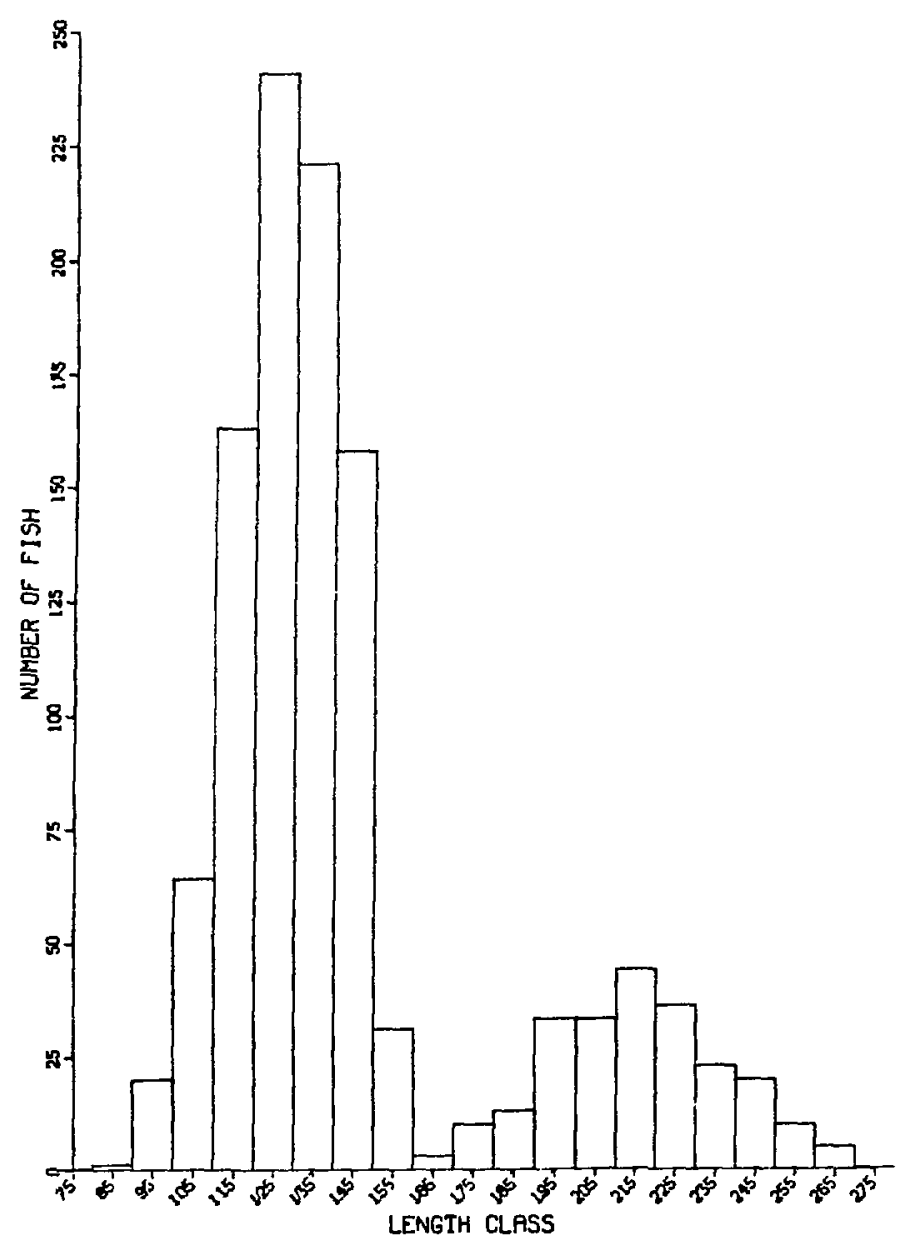

Fig. 8. Length-frequency data for white crappie collected by trap nets in Conowingo Pond, March 1974. 


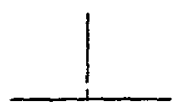

Age Structure from Length-Frequency Data

the full parameter vector $\Theta$ had to be used, because of the apparent discrepancies in the data. Two important points emerge from this example: $(a)$ the age-length key is valicl only for the catch on which it is based, and $(b)$ in reporting fish-length data it is important to back-calculate all the lengths to a standard time. The last print is extremly important if the catch over a year is to be summarized and used for production calculations.

\section{CONCLUSION}

We have used the length-frequency data in conjunction with the age. length key to obtain maximum likelihood estimates of the age structure in the population. The simulation results and examples presented lead us to believe that proper estimation of the age-length key will result in good estimates of the age structure. Since knowledge of the age structure is useful in estimating population parameters, such as grow th and mortality, it is therefore important that proper sampling methods be used for estimating the age-length key. The model can be used as follows to obtain an "optimal" subsampling scheme for age determination.

1. Obtain a length-frequency distribution for a fish catch.

2. Use the techniques described to obtain (a) estimate of modes. (b) estimate of variances, and (c) estimate of proportions.

3. Use these results to determine the "optimal" sample size for age determination.

4. Obtain an age-length key'.

5. Use the age-length key to re-estimate the proportions.

6. Re-evaluate step 3 and if the change in the optimal sample size is negligble, stop; otherwise, obtain additional samples for age-length key determination and repeat steps 3-6.

The algorithm described in steps $1-6$ above has not been examined in this study. We hope to adoress this problem in mole detail at at later date.

In addition to applying knowledge of the age structure to estimate functional parameters of fish populations, age distributions can be used in the context of evaluating the potential effects of power plant operations on fish populations. If an appropriate control system is available, then the age structures of fish in the control and stressed areas for the same time periods could be compared. Assume that the fish in a stressed area cannot migrate to and from the control area and that the two systems were similar before the intervention (preoperational period) by a power plant. Differential changes in the values of the mean lengths $\left(\mu_{i} s\right)$ and the proportions $\left(\rho_{i}\right.$ 's) between the 


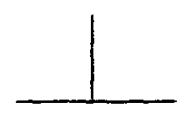

two areas can be tested for. In other words, a statistically significant dif. ferential change in the population characteristics in the stressed area as compared to the control area may be reflected in the estimated values of the parameters of the model ( $\mu_{i}$ 's and $\rho_{i}$ 's). For example. if the operation of a power plant increases the growth sate of certain age classes, then the estimated mean lengths for these age classes will be greater than the mean lengths in the control area during the same period. If the mortality rate of an age class increases in the stressed area, then a smaller proportion of that age class will exist in the stressed area as compared with the control area.

In the preceding discussion we have assumed that the control and stressed systems were similar before power piant intervention. This assumption is not realistic for natural systems. A more realistic assumption would be that when both the systenus vary naturally without intervention, there exists a constant structural relationship between the two areas. This constant relationship would be reflected by i constant value $r_{i}$ for the ratio of the proportions, $\rho_{i}$ s. for age $i$ between the two areas. This ratio can be estimated initially from the preoperational data. Changes in the value of this ratio after the start of plant operation would serve as an index of impact (see Thomas, in this volume, for a further discussion of the use of ratios).

\section{ACKNOWLEDGMENTS}

The authors wish to express their appreciation to W. Van Winkle and J. J. Beauchamp for their constructive criticism of the manuscript.

\section{LITERATURE CITED}

Allen, K. R. 1966. Determination of age distribution from IBM 7079, 7094, age-length keys and length distributions, Fortran IV. Trans. Am. Fish. Soc. 95:230-231.

Chadwick, E. M. P. 1976. Ecological fish production in a small Precambrian shield lake. Environ. Biol. Fish. 1:13-60.

Cohen, A. C. 1966. Discussion of "Estirnation of parameters for a mixture of normal distributions by Victor Hasselblad." Technometrics 8:445-446.

- 1967. Estimation in mixtures of two normal distributions. Tech. nometrics 9:15-28.

Cramer, H. 1974. Mathematical methods of statistics. Princeton Univ. Press, Princeton, New Jersey. 575 p.

Davis, J. 1959. Management of channel catfish in Kansas. Univ. Kansas, Mus. Nat. Hist., Misc. Publ. No. 21. 56 p.

Dick, N. P., and D. C. Bowden. 1973. Maximum likelihood estimation for mixtures of two normal distributions. Biometrics 29:781 -790 . 


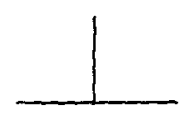

Age Structure from Length-Frequency Data

Fuston, E. T. 1976. Trophic spectrum, p. 4-1 8 to 442. In T. W. Robbins and D. Mathur [eds.] Postoperational report No. 5 on the ecology of Conowingo Pond for the period of July 1975-December 1975. IchthyoJogical Assuciates Inc., Drumore, Pennsylvania.

Finnell. J. C., and R. M. Jenkins. 1954. Growth of channel catfish in Okldhoma waters: 1954 revision. Okla. Fish. Res. Lab., Rep. No. 41.37 p.

Harter, H. L. 1952. Expected values of normal order statistics. Biometrika 48:151-165.

Hasselblad, V. 1966. Estimation of parameters for a mixture of normal distributions. Technometrics $8: 431-444$.

Ketchen, K. S. 1950. Stratified subsampling for determining age distributions. Trans. Am. Fish. Soc. 79:205--212.

Kumar, K. D., and E. H. Nicklin. 1976. Comparison of some models for security price behavior. Proc. 7th Annu. Pittsburg Conf. Modeling Simulation 7:98-103.

Mathur. D., P. G. Heisey, and N. C. Magnusson. 1975. Age and growth, p. 4-33 to 4-48. In T. W. Robbins and D. Mathus [eds.] Postuperational report No. 3 on the ecology of Conowingo Pond for the period of July 1974-De.ember 1974. Ichthyological Associates Inc., Drumore, Pennsy]. vania.

MacDonald, P. D. M. 1971. Comment on "An estimation procedure for mixture of distributions" by Choi and Bulgren. J. Roy. Siat. Soc. B. 33:326-329.

Neldet, J. A., and R. Mead. 1965. A simplex method for function minimization. Comput. J. 7:308-313.

Pearson, K. 1894. Contributions to the mathematical theory of evolution. Phil. Trans. Roy. Soc. 185:71-110.

Rao, C. R. 1952. Advanced statistical methods in biometric tesearch. Wiley and Sons, New York. 390 p.

Ricker, W. E. 1975. Computation and interpretation of biological statistics of fish populations. Fish. Res. Board Can., Bull. 191.382 p.

Robbins, T. W., and D. Mathur. 1974. Peach Bottom Atomic Power Station preoperational report on the ecology of Conowingo Pond for Units No. 2 ano 3. Ichthyological Associates, Inc., Drumore, Pennsylvania. 349 p.

Robbins, T. W., and D. Mathur. 1976. Peach Bottom Atomic Power Station postoperational report Nu. 5 on the ecology of Conowingo Pond for Units No. 2 and 3. Ichthyological Associates, Inc., Drumore, Pennsylvania.

Seber, G. A. F. 1973. The estimation of animal abundance and related parameters. Hafner Bros, New York. 506 p.

Stevens, R. E. 1959. The white and channel catfishes of the Santee-Cooper Reservoir and Tailrace Sanctuary, p. 203-219. In Proc. Thirteenth Annu. Conf., S.E. Assoc. Game Fish Comm. 